\title{
TOM22, a core component of the mitochondria outer membrane protein translocation pore, is a mitochondrial receptor for the proapoptotic protein Bax
}

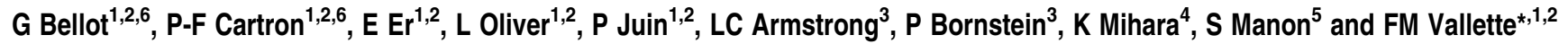

The association of Bax with mitochondria is an essential step in the implementation of apoptosis. By using a bacterial two-hybrid assay and crosslinking strategies, we have identified TOM22, a component of the translocase of the outer mitochondrial membrane (TOM), as a mitochondrial receptor of Bax. Peptide mapping showed that the interaction of Bax with TOM22 involved the first alpha helix of Bax and possibly two central alpha helices, which are homologous to the pore forming domains of some toxins. Antibodies directed against TOM22 or an antisense knockdown of the expression of TOM22 specifically inhibited the association of Bax with mitochondria and prevented Bax-dependent apoptosis. In yeast, a haploid strain for TOM22 exhibited a decreased expression of TOM22 and mitochondrial association of ectopically expressed human Bax. Our data provide a new perspective on the mechanism of association of Bax with mitochondria as it involves a classical import pathway.

Cell Death and Differentiation (2007) 14, 785-794. doi:10.1038/sj.cdd.4402055; published online 10 November 2006

Apoptosis is a cell death program, which is central in many aspects to metazoan cell physiology and pathology. ${ }^{1}$ Proteins of the Bcl-2 family are key players in the execution phase of apoptosis and their main functions is to control the release of apoptogenic proteins, such as cytochrome $c$ (cyt $c$ ) and apoptosis inducing factor (AIF) from the mitochondria. ${ }^{2}$ The $\mathrm{Bcl}-2$ family is composed of antiapoptotic members such as $\mathrm{Bcl}-2$ and proapoptotic proteins such as Bax or Bak, which share several domains of homology called $\mathrm{BH} .{ }^{1}$ In addition to these proteins, a third Bcl-2-related family of proteins have been identified as major amplifiers and/inducers of apoptosis. ${ }^{2}$ The latter family has a homology to Bcl-2 limited to the $\mathrm{BH} 3$ domain and thus is called the BH3 only proteins. ${ }^{2}$ The double knockout of Bax and Bak renders cells completely resistant to cell death ${ }^{2}$ highlighting the essential role of these proteins during apoptosis.

The determination of the solution structure of Bax showed its organization around nine $\alpha$-helices $(\mathrm{H} \alpha 1 \text { to } \mathrm{H} \alpha 9)^{3}$ of which $\mathrm{H} \alpha 2$ contained most of the $\mathrm{BH} 3$ domain and $\mathrm{H} \alpha 5$ and $\mathrm{H} \alpha 6$, a putative pore forming domain that has been shown to be involved in the integration of Bax into the membrane. ${ }^{4,5}$ Bax resides in an inactive state in the cytosol in many resting cells and is translocated to the mitochondria at the onset of apoptosis. $^{6}$ This translocation is associated with major conformational changes in Bax as both the amino-terminal end $(\mathrm{N}-\mathrm{T})$ and carboxy terminal end $(\mathrm{C}-\mathrm{T})$ become exposed facilitating its mitochondrial addressing and membrane insertion. 5,7 Bax mitochondrial membrane insertion and oligomerization is closely associated with the release into the cytosol of several intermembrane space proteins such as cyt $c$, second mitochondrial apoptotic factor (Smac) and AIF. ${ }^{2}$ The nature of the different stimuli involved in the activation or in the inhibition of Bax is still largely unknown although this step remains one of the most critical points of control of the apoptotic program during which therapeutic interventions can be envisaged. ${ }^{2}$

The mitochondrial targeting signals of $\mathrm{Bcl}-2$ and $\mathrm{Bcl}-\mathrm{XI}$ have been unambiguously assigned to their C-T. ${ }^{8}$ However, the situation seems to be more complex for Bax since, despite the homology between the C-T of Bcl-2 and Bax, the C-T of Bax, which encompasses the $\mathrm{H} \alpha 9$, does not have conventional mitochondrial targeting features as it cannot, single-handedly, support the translocation of a reporter protein to the mitochondria. ${ }^{9,10}$ However, mutation of specific amino acids or post-translational modifications such as phosphorylation can render this C-T competent for mitochondrial addressing. ${ }^{11}$ We have recently shown that Bax contains a functional mitochondrial-addressing signal in its $\mathrm{N}-\mathrm{T}$, which encompasses $\mathrm{H} \alpha 1$. Point mutations in the $\mathrm{H} \alpha 1$ of $\mathrm{Bax}$ or the overexpression of a chimera protein in which this helix was fused to the cytosolic Red Fluorescence Protein inhibited Baxdependent apoptosis. ${ }^{10}$

\footnotetext{
${ }^{1}$ INSERM U601, France; ${ }^{2}$ Université de Nantes, Faculté de Médecine, Nantes, Cedex, France; ${ }^{3}$ Department of Biochemistry, University of Washington, Seattle, WA, USA; ${ }^{4}$ Department of Molecular Biology, Graduate School of Medical Science, Kyushu University, Fukuoka, Japan and ${ }^{5}$ CNRS UMR 5095, Université Bordeaux 2 , Bordeaux, France

*Corresponding author: FM Vallette, IFR 26, UMR601 INSERM, Université de Nantes, Faculté de Médecine, 9 Quai Moncousu F-44035, Nantes Cedex 01, France. Tel: + 33 240084081; Fax: + 33 240084082;

E-mail: francois.vallette@univ-nantes.fr

${ }^{6}$ These two authors contributed equally to this work.

Keywords: apoptosis; Bax; mitochondria; TOM; receptor

Abbreviations: C-T, carboxy terminal end; IVT, in vitro translated; N-T, amino-terminal end; TOM, translocase of the outer membrane of mitochondria

Received 12.4.06; revised 04.9.06; accepted 26.9.06; Edited by JC Martinou; published online 10.11.06
} 
We have attempted to identify mitochondrial receptors to Bax and found that translocase of the outer membrane of mitochondria TOM22, a receptor for nuclear encoded mitochondrial proteins, was a receptor for $\mathrm{Bax} \mathrm{H} \alpha 1$. The functional inhibition of this interaction interfered with Bax mitochondrial addressing and apoptosis underlining the importance of this interaction in cell death.

\section{Results}

The association of Bax with mitochondria is trypsin sensitive. Once inserted into the mitochondrial membrane, Bax induced the formation of the so-called mitochondrial membrane permeabilization (MMP) alone or in combination with other proteins and/or lipids. ${ }^{12}$ Numerous study have shown that in a simple cell-free assay using isolated mitochondria and purified or in vitro translated (IVT) Bax could accurately reproduce early events of the Bax-induced permeabilization of the mitochondria. ${ }^{10,13-15}$ In order to elucidate the receptors involved in Bax association with mitochondria, we subjected isolated mitochondria to a mild proteolysis by trypsin using a protocol described earlier for the identification of components of the outer membrane import machinery. ${ }^{16}$ Isolated rat liver mitochondria were treated with 0,5 or $50 \mu \mathrm{g} / \mathrm{ml}$ trypsin for $30 \mathrm{~min}$ at $4^{\circ} \mathrm{C}$ (see Materials and Methods) before immunoblot analyses of selected mitochondrial proteins. As shown in Figure 1a, the treatment of purified rat liver mitochondria for $30 \mathrm{~min}$ at $4^{\circ} \mathrm{C}$ with trypsin $(0-50 \mu \mathrm{g} / \mathrm{ml})$, specifically degraded outer membrane proteins with cytosolic exposed domains such as the peripheral benzodiazepine receptor, the translocases of the outer membrane, TOM20 and TOM22 but affect neither the voltage-dependent anionic channel 1 (VDAC 1), an integral outer membrane protein, intermembrane space proteins such as Smac/Diablo or AIF nor cyt $c$ and F1ATPase, two inner membrane proteins.

The association of two variants of Bax with mock- and trypsin-treated isolated mitochondria were assayed viz. Bax $\alpha$, Bax $\alpha$ activated by a preincubation with truncated form of Bid (p13-tBid) ${ }^{17}$ and Bax $\Psi$, a variant, which corresponds to a deletion of the first $19 \mathrm{~N}-\mathrm{T}$ amino acids of $\operatorname{Bax} \alpha \cdot{ }^{18}$ We also used constructs in which the RFP was fused to two putative mitochondrial targeting signals in $\mathrm{Bax}$ (i.e. $\mathrm{H} \alpha 1$ and $\mathrm{H} \alpha 9$ ). ${ }^{9,10}$ With respect to the localization of these helices, the $\mathrm{H} \alpha 1$ of Bax was fused at the N-T of the RFP to form a H $\alpha 1-\mathrm{RFP}$ construct while $\mathrm{H} \alpha 9$ and a $\mathrm{H} \alpha 9$ mutant containing a single deletion of $S 184^{9}$ were fused to the C-T of RFP to form the RFP-H $\alpha 9$ and RFP-H $\alpha 9 \Delta$ S184 constructs.

The proteins were synthesized in vitro, labeled with ${ }^{35} \mathrm{~S}$ (IVT proteins) and incubated with $50 \mu \mathrm{g}$ of isolated mock- or trypsin-treated mitochondria and their association with the organelle was assayed by SDS-PAGE and autoradiography analysis of the mitochondrial pellets. Bax $\alpha$ binds poorly to mitochondria in the cell-free assay unless activated by an apoptotic signal from tBid. ${ }^{19}$ As shown in Figure 1b, the low binding of Bax $\alpha$ observed in mock-treated mitochondria was completely abolished by a $5 \mu \mathrm{g} / \mathrm{ml}$ trypsin pretreatment. The mitochondrial association of $\operatorname{Bax} \alpha$ was considerably enhanced once activated by tBid and its binding was affected a

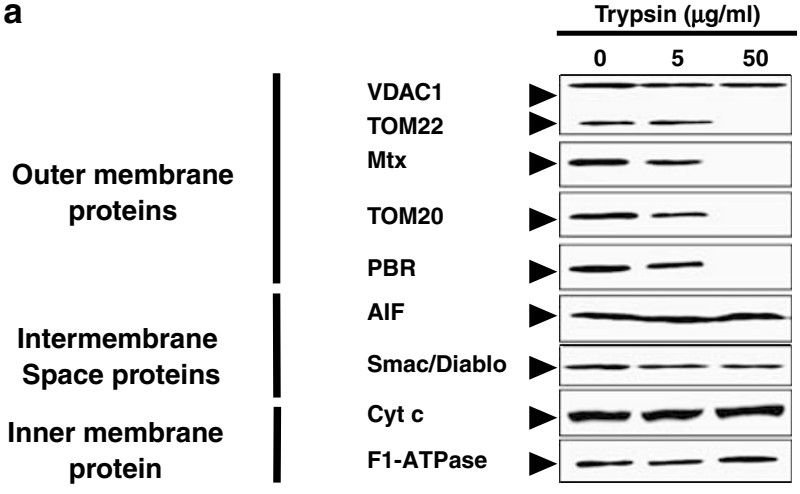

b

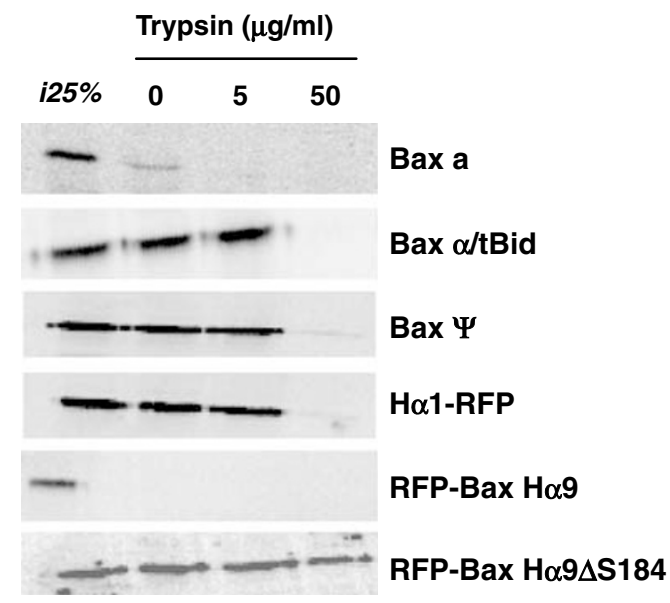

Figure 1 Bax interacts with a proteinaceous receptor. (a) Mild trypsin treatment of mitochondria. Purified rat liver mitochondria (50 $\mu \mathrm{g}$ protein) were treated with increasing concentrations of trypsin for $30 \mathrm{~min}$ at $4^{\circ} \mathrm{C}$ before immunoblot analysis of selected mitochondrial protein. This immunoblot is representative of at least five independent experiments. (b) Association of Bax construct with trypsin-treated mitochondria. IVT radio labeled Bax constructs were added to mitochondria, control (0) or treated with 5 or $50 \mu \mathrm{g} / \mathrm{ml}$ trypsin; I25\%: $25 \%$ of the original input of IVT proteins. This immunoblot illustrates the results of at least five independent experiments

only by a $50 \mu \mathrm{g} / \mathrm{ml}$ trypsin pretreatment (Figure $1 \mathrm{~b}$ ). Similarly, the spontaneous association of Bax $\Psi$ was unaffected at $5 \mu \mathrm{g} / \mathrm{ml}$ trypsin but inhibited by a $50 \mu \mathrm{g} / \mathrm{ml}$ trypsin pretreatment (Figure 1b). In addition, the proteolytic pretreatment affected the binding of $\mathrm{H} \alpha 1-\mathrm{RFP}$ at $50 \mu \mathrm{g} / \mathrm{ml}$, but not that of RFP$\mathrm{H} \alpha 9 \Delta \mathrm{S} 184 \mathrm{Bax}$ (Figure 1b) while the RFP-H $\alpha 9$ was never seen to associate with mitochondria under any of our conditions. Of note, the cell-free mitochondrial import of chimerical proteins in which the presequence of the nuclear encoded human mitochondrial protein COX 8 (subunit eight of the cyt $c$ oxydase) was fused to the N-T of the RFP (pre-COX VIII-RFP), was impaired by the trypsin pretreatments of the mitochondria (data not shown).

Physical interaction between Bax and TOM22, a mitochondrial receptor. We have recently shown that the $\mathrm{BH} 3$ only proteins Bid and PUMA interacted with the $\mathrm{H} \alpha 1$ of $\mathrm{Bax}$ using a bacterial two hybrid screen. $^{20}$ The physical interaction between $\mathrm{Bax} \mathrm{H} \alpha 1$ and these $\mathrm{BH} 3$ only proteins was confirmed by both structural and functional analyses. ${ }^{20}$ 
During this screening, we found that the mitochondrial protein TOM22 was also capable of interacting with Bax $\mathrm{H} \alpha 1-\mathrm{RFP}$ but not with RFP or the RFP-H $\alpha 9 \Delta \mathrm{S} 184 \mathrm{Bax}$ chimera (data not shown). TOM22 has been shown to be involved in protein translocation into mitochondria and has a dual role, as it is a component of the general insertion pore together with the pore-forming protein TOM40 and, as such, is involved in protein translocation across the mitochondrial outer membrane. ${ }^{21}$ TOM22 is also an import receptor for proteins lacking conventional mitochondrial presequences ${ }^{22}$ and contains a large cytosolic domain, which has been shown to be sensitive to proteolysis. ${ }^{23,24}$

All these data were consistent with a putative role for TOM22 as a mitochondrial receptor of Bax. To strengthen this contention, we used several strategies including cell-free assays and in vitro analyses in resting or apoptotic cells. Firstly, we used a linear peptide scan derived from epitope mapping ${ }^{25}$ in which the whole sequence of Bax was decomposed into 12 mer peptides overlapping by 10 residues covalently bound to a nitrocellulose membrane. The membranes were incubated with mitochondrial extracts and the presence of proteins bound to the Bax peptides was analyzed by immunoblots (see Materials and Methods). As shown in Figure $2 \mathrm{a}$, several domains of Bax were strongly labeled with anti-TOM22 antibodies: the central region of the $\mathrm{H} \alpha 1$ sequence (namely KTGALLLQ) and the short loop between the central helices $\mathrm{H} \alpha 5$ and $\mathrm{H} \alpha 6$ (namely LCTKVPEL). Of note, these two sequences have been shown to be implicated in the addressing and the insertion of Bax into mitochondrial membrane. ${ }^{4,5}$ Interestingly, a weaker interaction was observed with the hydrophobic $\mathrm{H} \alpha 9$ and the two regions flanking the $\mathrm{BH} 3$ domain of Bax (Figure 2a). The interaction of VDAC with Bax has been suggested ${ }^{26}$ but only a faint association of Bax peptides with VDAC was observed under our conditions (Figure 2a), suggesting that the Bax/VDAC association does not occur through 'linear' primary sequences.

Secondly, crosslinking experiments were performed to categorize the Bax/TOM22 interaction. We used Bax $\Psi$, $\mathrm{H} \alpha 1-\mathrm{RFP}$ and RFP-H $\alpha 9 \Delta \mathrm{S} 184$ but with two different crosslinkers (either ethylene glycolbis succinimidylsuccinate (EGS) or dissuccinimidyl suberate (DSS)). As shown in Figure $2 b$, in the presence of either crosslinker, the molecular weight of $\mathrm{H} \alpha 1-\mathrm{RFP}$ associated with mitochondria shifted from 30 to $46 \mathrm{kDa}$ and that of Bax $\Psi$ from 19 to $35 \mathrm{kDa}$. In contrast, no change in the apparent molecular weight of RFP-H $\alpha 9 \Delta \mathrm{S} 184$ was observed under the same conditions in the presence of mitochondria (Figure $2 \mathrm{~b}$ ) or higher amounts of proteins (data not shown). As the change in the apparent molecular weights was consistent with an association of these proteins with TOM22, we immunoprecipitated the crosslinked products with antibodies directed against human TOM22 or TOM20, another receptor of the outer membrane translocase. As shown in Figure $2 \mathrm{~b}, \mathrm{H} \alpha 1$-RFP and $\mathrm{Bax} \Psi$ crosslinked products were immunoprecipitated with anti-TOM22 antibodies but not with anti-TOM20 antibodies.

Thirdly, to confirm the physical association between Bax $\alpha$ and TOM22 under more physiological context, we immunoprecipitated TOM22 and Bax $\alpha$ from cellular extracts obtained from resting or STS-treated (i.e. apoptotic) GBM Bax $(+)$ cells. ${ }^{17}$ Western blots analysis of proteins co-immunoprecipi- tated with TOM22 or Bax $\alpha$ showed that in resting cells TOM22 was associated with TOM40 and that it became associated with $\mathrm{Bax} \alpha$ under apoptotic conditions (Figure 2c). On the other hand, $\mathrm{Bcl}-2$ was co-immunoprecipitated with Bax in resting cells and in apoptotic cells (Figure 2c). Of note, the specificity of this experiment was provided by the observation that VDAC, an abundant protein of the outer membrane of mitochondria, was not immunoprecipitated by anti-TOM22 antibodies under our conditions.

Next, we used Blue native gel electrophoresis, a method which has been extensively used for the qualitative study of mitochondrial proteins organization, to examine the complexes formed by Bax and TOM22 during UV-induced apoptosis in Hela cells (Figure 2d). In mitochondria of untreated cells, the vast majority of endogenous Bax was present in a major low molecular weight complex, which is likely to correspond to monomers. TOM22 was found in a complex of high molecular $(\geq 900 \mathrm{KDa})$ under the same conditions. Of note, a small proportion of TOM22 appears nonetheless to comigrate with Bax. At $12 \mathrm{~h}$ after the induction of apoptosis, Bax was organized in complexes of higher orders with molecular weights ranging from $20 \mathrm{KDa}$ to $\geq 900 \mathrm{KDa}$. Quite remarkably, TOM22 exhibited a similar pattern. After $24 \mathrm{~h}$, Bax was mostly present in two complexes of 20 and $900 \mathrm{KDa}$ while TOM22 was for the most part present in a $450 \mathrm{KDa}$ complex. These results suggest that the association of Bax with TOM22 is massive at the early stage of apoptosis but transient as it broke down at latter stage. A time course assay in a cell-free assay where IVT Bax was crosslinked to mitochondria gave similar results (Supplementary Figure S1).

Involvement of TOM22 in the association of Bax with mitochondria and in subsequent apoptosis. Import of precursor proteins into isolated mitochondria can be inhibited by antisera raised against components of the translocation machinery of the outer membrane. ${ }^{27}$ We saturated rat liver mitochondria either with anti-TOM22 or with antibodies raised against several other outer membrane proteins (i.e. TOM20, and metaxin 1, PBR and VDAC 1) and analyze the association of $\operatorname{Bax} \alpha$ under these different conditions. As shown in Figure $3 a$ and $b$, the preincubation of mitochondria with anti-TOM22 antibodies specifically inhibited activated Bax $\alpha$ binding to mitochondria whereas other antibodies had no effect. Similar results were obtained with $\operatorname{Bax} \Psi$ while the association of Bax $\Delta S 184$ to the organelle was affected by neither antibodies (Figure $3 b$ ). As a positive control for protein import into mitochondria, we used pre-COX VIII-RFP construct and antibodies raised against mitochondrial import receptors (i.e. TOM20, TOM22, Metaxin 1) inhibited its association with mitochondria (Figure 3b).

To address the question of the involvement of TOM22 in an in vitro model of induction of apoptosis, we microinjected antibodies raised against TOM22 into rat glioma A15A5 cell line which express $\operatorname{Bax} \alpha$, and then induced apoptosis with staurosporine (STS). The STS-induced apoptosis was inhibited by anti-TOM22 antibodies in a dose-dependent manner (Supplementary Figure S2). On the other hand, microinjection of antibodies directed against other mitochon- 


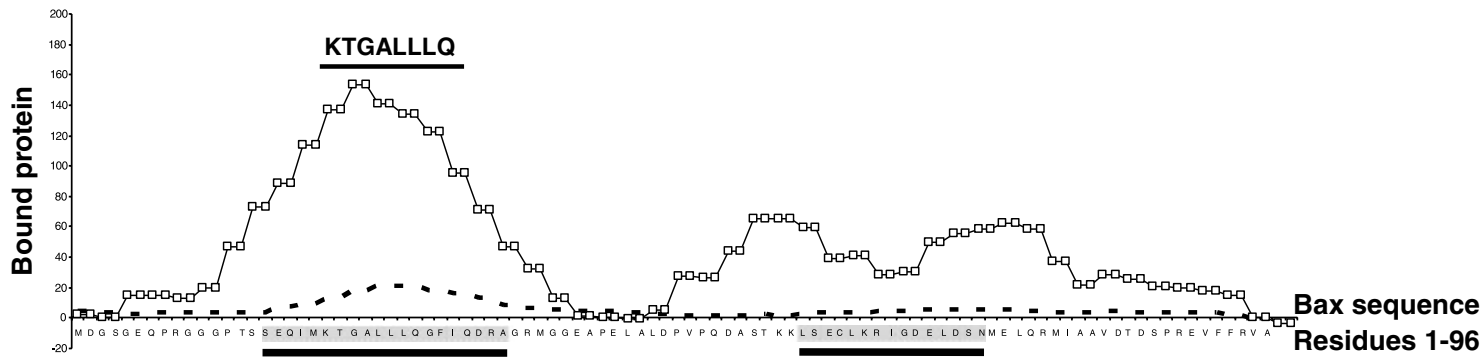

$\alpha 1$-helix

$\mathrm{BH} 3$

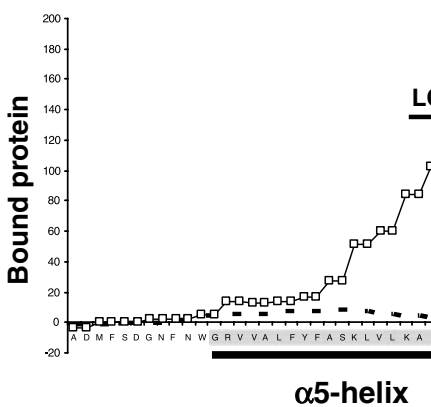

$$
\begin{aligned}
& -\square-\text { bound Tom22 } \\
& \text { - } \quad \text { - } \text { - bound VDAC }
\end{aligned}
$$
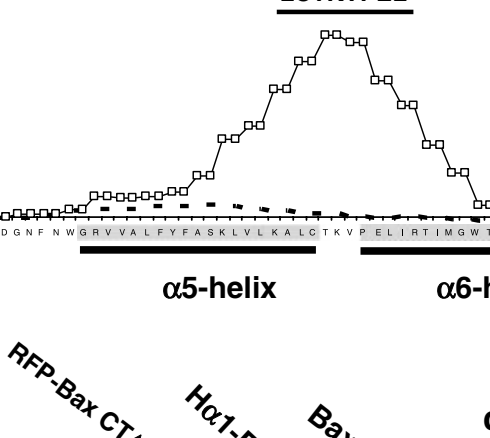

C

IP-TOM22
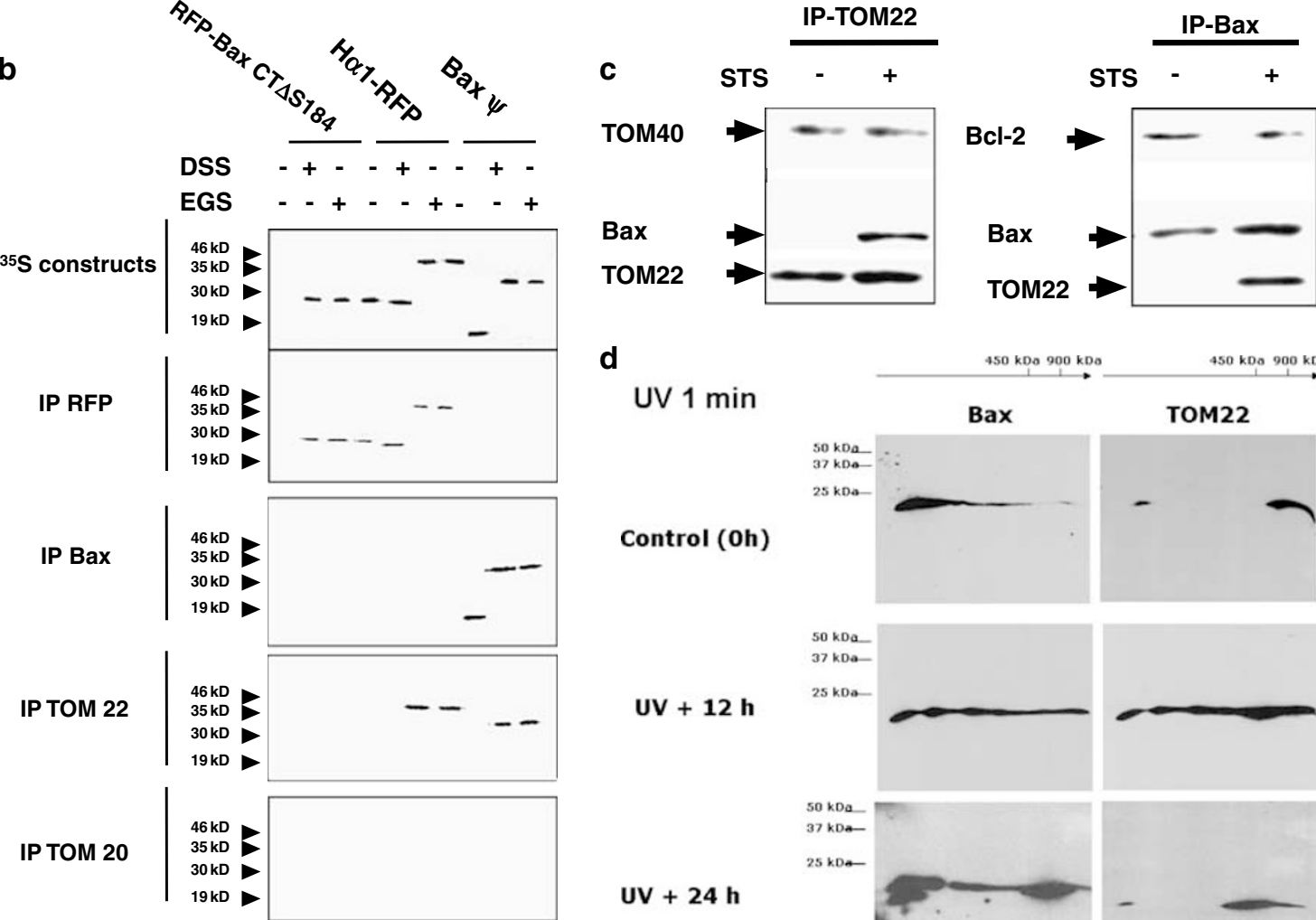

d $450 \mathrm{kDo} 900 \mathrm{kDo}$

UV $1 \mathrm{~min}$

Bax

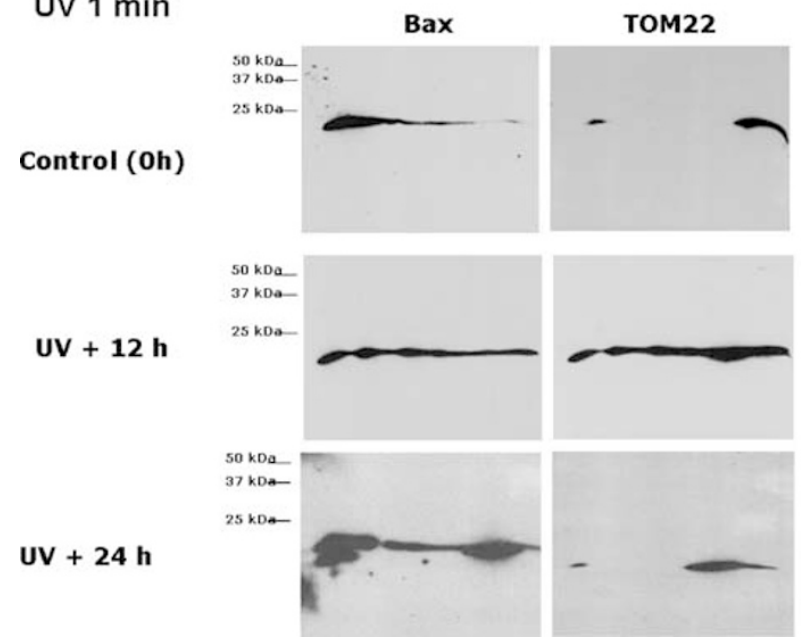


drial receptors (e.g. TOM20, metaxin 1 or PBR) did not affect STS-induced apoptosis (Figure 3c).

Next, we used human glioblastoma multiforme (GBM) cells deficient in Bax (Bax (-) GBM) or in Bak (Bak (-) GBM). ${ }^{17}$ These cells were microinjected with either control IgG or antiTOM22 antibodies. Microinjection of anti-TOM22 antibodies inhibited STS-induced apoptosis in Bax (+) GBM cells, while no differences in the low percentage of cell death were detected between Bax (-) GBM cells injected with antiTOM22 and control antibodies (Figure 3d). Of note, Bak seems to have little or no effect on TOM22-dependent apoptosis as shown by similar experiments performed in Bak (-) GBM cells (Figure 3d).

The decrease of the expression of TOM22 abolished Bax association with mitochondria in mammals and in yeast. To demonstrate further the functional role of TOM22 in Bax-dependent apoptosis, full-length antisense TOM22 cDNA was stably transfected into Bax (+) GBM cells to generate TOM22 null cells (i.e. TOM22-AS). In yeast, the gene disruption of TOM22 has been reported to affect mitochondrial function. ${ }^{23}$ Indeed, mitochondrial protein import in TOM22-AS-treated GBM cells was severely impaired to the same extent than that observed in TOM20AS-treated GBM cells (Figure 4a) and the viability of these cells was reduced unless cultured in the presence of high levels of glucose (Supplementary Figure S3). We chose cell culture conditions under which TOM22-AS cells were still viable and expressed similar amounts of mitochondrial proteins and other members of the $\mathrm{Bcl}-2$ family comparable to that found in TOM22 expressing cells (Figure 4b). The subcellular localization of Bax in STS-treated or in control TOM22-AS was analyzed by cell fractionation (Figure 4c) and by laser confocal microscopy (Supplementary Figure S4). Both methods indicated that Bax was efficiently translocated from the cytosol to the mitochondria in cells expressing TOM22 while this translocation was strongly inhibited in TOM22-AS cells (Figure 4c; Supplementary Figure S4). Of note, no changes in the subcellular localization of $\mathrm{Bcl}-2, \mathrm{Bcl}-\mathrm{Xl}$ and $\mathrm{Bak}$ were observed in TOM22-AS cells (Supplementary Figure S4), suggesting the specificity of the antisense treatment. In agreement with its role as Bax receptor, the lack of TOM22 reduced the amount of cell death caused by STS treatment in TOM22-AS Bax (+) GBM cells to a level similar to that in Bax (-) GBM
STS-treated cells (Figure 4d). In contrast, the reduced expression of the mitochondrial import receptor TOM20 by a similar antisense treatment had little or no influence on STSinduced apoptosis although it affect similarly the import of a reporter mitochondrial protein (Figure 5). This result suggests that the effect of TOM22 antisense on Bax association with mitochondria is specific. Of note, in TOM22-AS cells, the association of Bax $\Psi$ but not that of Bax $\Delta S 184$ with mitochondria was strongly inhibited (Figure 6), suggesting again that the two mitochondria-bound forms of Bax interacted with different mitochondrial binding sites.

The heterologous expression of human Bax in yeast has been useful to understand molecular aspects of Bax/ mitochondria interactions. The disruption of the gene TOM22 is lethal in yeast ${ }^{23}$ and thus we used a diploid strain, heterozygote for TOM22. The expression of Bax $\Psi$ which is capable of spontaneous association with yeast mitochondria, was achieved in TOM22 +/+ and TOM22 +/- strains. Western blots quantification showed that mitochondria isolated from the heterozygote strain contained less TOM22 than mitochondria isolated from the corresponding wild type (Figure 7a) and it contained less Bax $\Psi$ at the mitochondria (Figure 7b). Bax-T174D, a variant of Bax exhibits a strong binding to mitochondria in yeast and as shown in Figure 7c-d, the time course of its mitochondrial association was impaired in TOM22 + / - when compared to that in the wild-type strain. These data are consistent with the hypothesis that Tom22 is also required for Bax-binding to yeast mitochondria.

\section{Discussion}

Several models have been proposed to account for the mitochondrial permeability induced by Bax during apoptosis and in all of them the interaction of Bax with the organelle plays an central role. ${ }^{28}$ Kuwana et al. ${ }^{12}$ have observed that Bax could induce a large permeabilization of liposomes in the absence of any proteins. Conversely, other results suggest that the presence of at least one mitochondrial protein was necessary for Bax to mediate outer MMP. ${ }^{29}$ It has been recently reported that an outer membrane mitochondrial protein, the modulator of apoptosis-1 (MAP-1), is a critical effector of Bax function. ${ }^{30}$ Indeed, we show in this work that the association of Bax with mitochondria requires TOM22, a mitochondrial outer membrane protein. However, as stated by Newmeyer and Ferguson-Miller, ${ }^{31}$ the latter observations are

Figure 2 Bax interacts with TOM22. (a) Binding of hTom22 to a peptide scan consisting of 12-mers derived from Bax. Mitochondrial extracts were incubated with the peptides containing membrane as indicated in the 'Materials and Methods'. The interaction of Tom22 with peptides were revealed by immunoblotting analysis using antihuman Tom22 antibody (clone 1C9-2, Sigma) (upper panel). As a negative control the binding of VDAC to the membrane was revealed by immunoblotting analysis using antihuman VDAC antibody (anti-porin 31HL, Calbiochem). The binding intensities of Tom22 or VDAC for Bax-derived peptides were determined by quantification using IPLab Gel software (Signal Analytics) and converted to sequence-specific normalized units in the graph. The intensities obtained for each peptide covering a given amino acid were added and divided by the number of peptides (TOM22: $\square-\square$; VDAC: -..--). (b) Crosslinking experiments were performed after the incubation of IVT ${ }^{35}$ S-labeled Bax constructs wit $\mathrm{h} 1 \mathrm{mg}$ mitochondria as described in (b) for $30 \mathrm{~min}$. Mitochondrial pellets were subjected to IP with $4 \mu \mathrm{g}$ of antibodies directed against RFP, Bax, TOM22 or TOM20. This autoradiography is representative of three independent experiments. (c) Interaction of Bax and TOM22 in untreated or STS-treated Bax ( + ) GBM cells. Cells were treated with STS as described in Materials and Methods section. Cells were sonicated and the resulting lysates were subjected to IP with either anti-TOM22, anti-Bax antibodies. We use as a control the IP of TOM20 by anti-TOM20 (data not shown). The specificity of the IP with anti-TOM22 antibodies was assessed by the presence of TOM40 in the immunoprecipitated complex and that of anti-Bax by the presence of Bcl-2. Note that in untreated cells, large amounts of Bcl-2 were immunoprecipitated with Bax, and that the induction of apoptosis decreased this association. Data illustrated are representative of three different experiments. (d) Apoptosis was induced by a brief UV treatment of Hela cells and cells were collected and mitochondria obtained after cell fractionation, as described by Cartron et al. ${ }^{5}, 12 \mathrm{~h}$ and $24 \mathrm{~h}$ after induction. Blue native gels were performed on Hela isolated mitochondria and the membranes were immunoblotted with anti-Bax or anti-TOM22 antibodies as described in Materials and Methods 

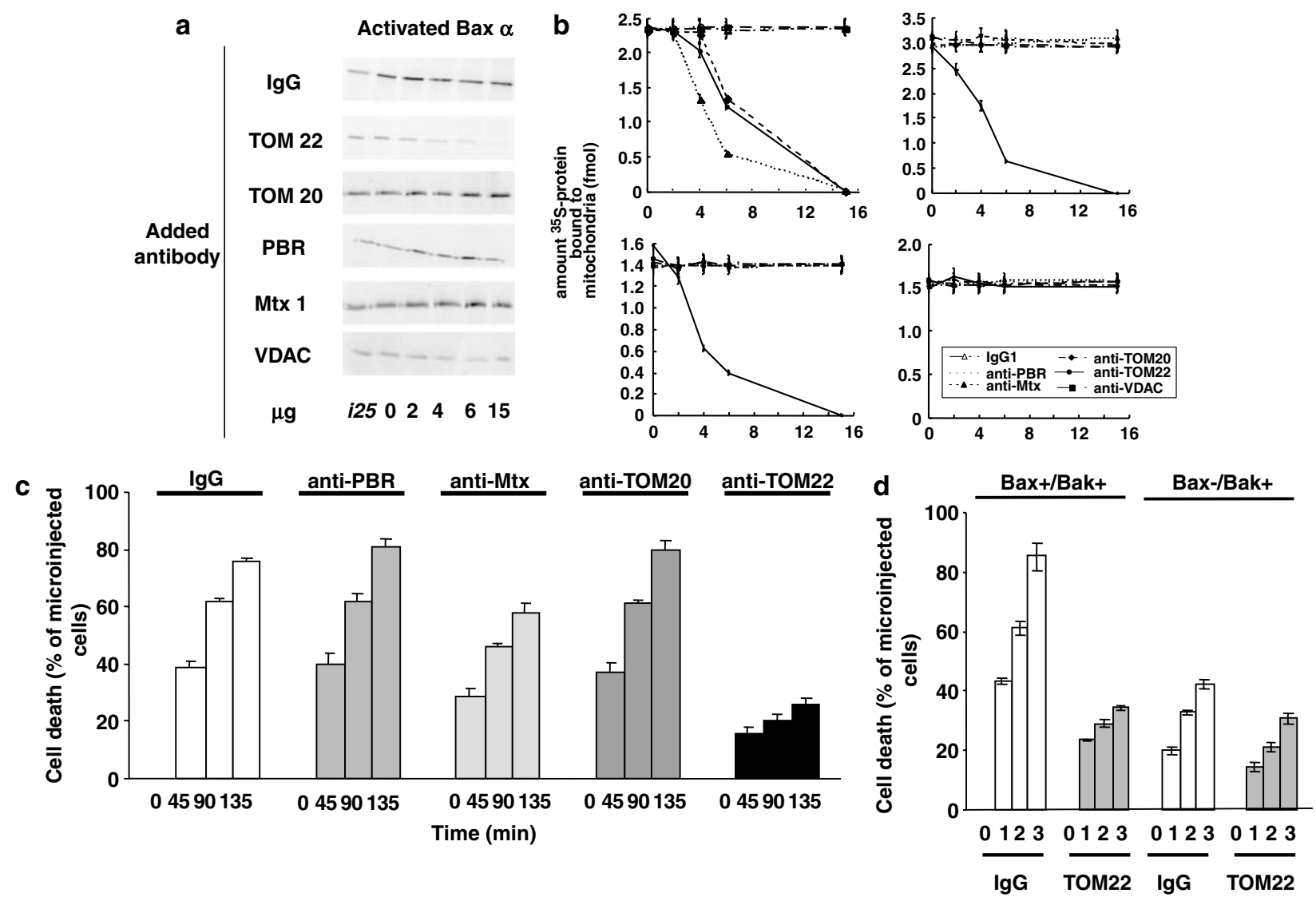

Figure 3 Antibodies directed against TOM22 specifically inhibit the binding of Bax to mitochondria. (a) Competition between increasing concentrations of antibodies (from 0 to $15 \mu \mathrm{g}$ ) directed against a panel of mitochondrial outer membrane proteins and the binding of IVT-activated Bax $\alpha$. Gel representative of three different experiments. (b) Quantification of the binding of $\operatorname{Bax} \alpha, \operatorname{Bax} \Psi$, Bax $\triangle S 184$ Bax and pre-COX VIII-RFP, performed from three different experiments as that illustrated in (a), using IPLab Gel software (Signal Analytics). (c) Rat glioma A15A5 cells, were microinjected with $15 \mu \mathrm{g}$ antibodies raised against selected receptors of the outer membrane of mitochondria viz. PBR, Metaxin 1 (Mtx), TOM20, TOM22 and control lgGs before induction of apoptosis by STS. Cell death was measured every 45 min as described in 'Materials and Methods'. (d) Inhibiting concentrations of anti-TOM22 (15 $\mu \mathrm{g})(\mathbf{\square})$ were microinjected into 100-150 human GBM cells expressing or not Bax and Bak $(B a x(+)$ Bak $(+)$; Bax $(+)$ Bak $(-)$; Bax (-) Bak (+) and Bak (-) Bax (-) GBM) before the induction of apoptosis by $2 \mu \mathrm{M} \mathrm{STS}$. Nonimmune lgG $(\square)$ was used as a control. Cell death was followed and quantified described in 'Materials and Methods', until almost all Bax $(+)$ Bak $(+)$ GBM cells were dead

not exclusive, as mitochondrial lipids could cooperate with Bax and mitochondrial proteins to form a mitochondrial receptor.

Like most Bcl-2 family members, Bax has a C-T hydrophobic $\mathrm{H} \alpha 9$, which has been hypothesized to be its transmembrane domain. However, unlike $\mathrm{Bcl}-2$ and $\mathrm{Bcl}-\mathrm{XI}$, Bax- $\mathrm{H} \alpha 9$ is not able to drive the mitochondrial binding of RFP $^{9,10}$ and experiments on isolated mitochondria did no support a role for $\mathrm{H} \alpha 9$ in the mitochondrial addressing of Bax. ${ }^{10}$ We have recently shown that mutations in Bax $\mathrm{H} \alpha 1$ abolished Bax $\alpha$ binding to mitochondria in a cell-free assay, and inhibited $\mathrm{Bax} \alpha$-induced apoptosis in vitro. ${ }^{10}$ This result suggested that $\mathrm{H} \alpha 1$ played an essential role in addressing $B a x$ to mitochondria and that the mechanisms of addressing of Bax to mitochondria are consequently distinct from that of $\mathrm{Bcl}-2$ or $\mathrm{Bcl}-\mathrm{XI}$.

In the present study, we have shown that Bax binding to mitochondria requires a protease sensitive partner (Figure 1). The two-hybrid approach allowed identifying TOM22 as a potential physical partner of Bax. This physical interaction was further confirmed on isolated mitochondria by crosslinking studies (Figure 2). The interaction Bax/TOM22 was triggered by apoptosis, as shown from co-immunoprecipitation (IP) of the two proteins in STS-treated but not in control cells (Figure 2). Functionally, both the microinjection of antiTOM22 antibodies and the knocked-down expression of TOM22 led to the absence of Bax-translocation and the inhibition of Bax-dependent apoptosis (Figure 3). Similarly, decreasing TOM22-expression in human and in yeast cells, led to a significant decrease in Bax-translocation (Figures 4 and 7). Our previous results suggested that $\mathrm{H} \alpha 1$ was involved in the addressing of Bax to mitochondria but that the membrane insertion domain of Bax was carried out by $\mathrm{H} \alpha 5$ and $\mathrm{H} \alpha 6,{ }^{5}$ as previously shown by others. ${ }^{4,32}$ Quite remarkably, TOM22 can also bind to a region linking the $\mathrm{H} \alpha 5$ and $\mathrm{H} \alpha 6$, suggesting that it might also be involved in the insertion of Bax in the outer mitochondrial membrane (Figure 2). Of course, we cannot eliminate the possibility that other proteins whose mitochondrial targeting is dependent on Tom22 specifically affect Bax translocation and apoptosis. It should be noted that no evidence for an interaction between $\mathrm{Bax} \mathrm{H} \alpha 9$ and TOM22 was ever found, supporting our previous reports that $\mathrm{H} \alpha 9$ is not required for any step in the whole process of Bax cytosol-to-mitochondria translocation. 
a

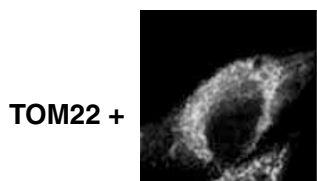

TOM precoX VIII

mito +
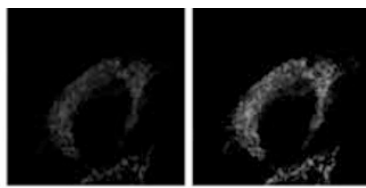

preCOX VIII
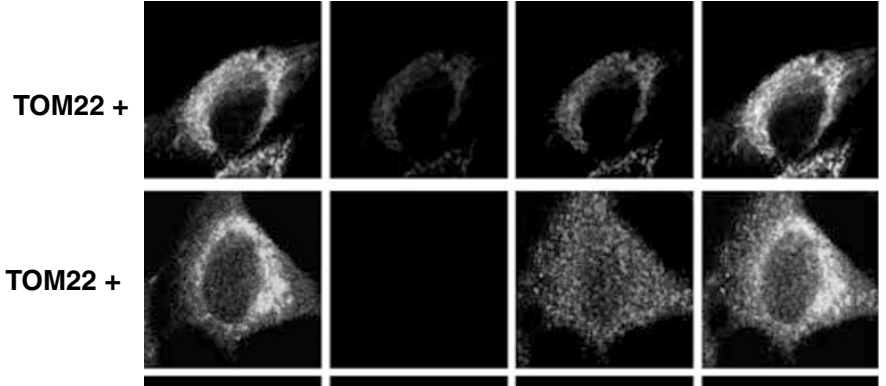

TOM20 +
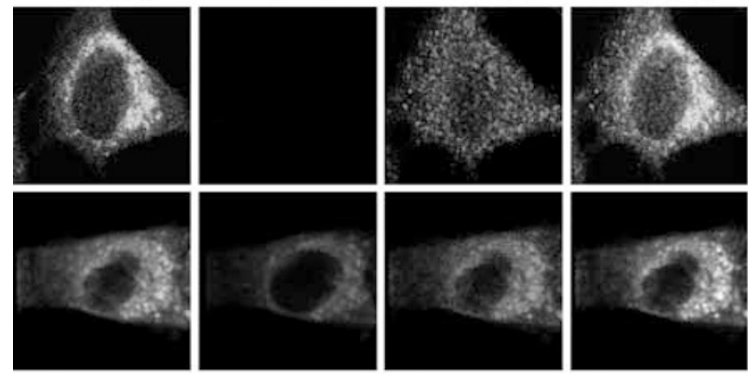

TOM20 -
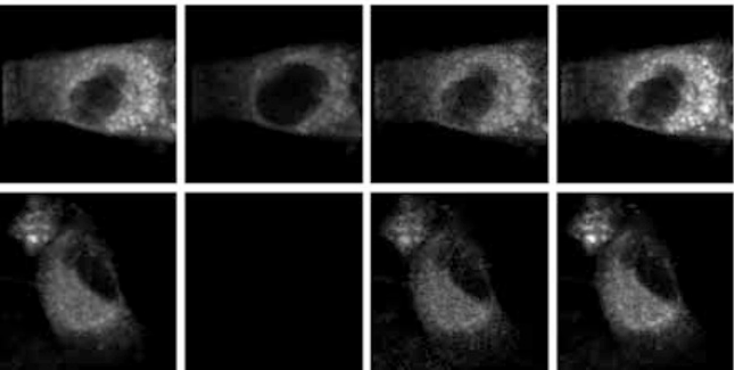

b

TOM22

PBR

VDAC

Cyt c

AIF

Smac/Diablo

F1-ATPase

c

\begin{tabular}{l|c} 
& $\begin{array}{c}\text { TOM22 } \\
\text { Cytosol }\end{array}$ \\
& $\begin{array}{c}\text { Actin } \\
\text { Bax }\end{array}$ \\
Mito & Bax \\
& Cox
\end{tabular}
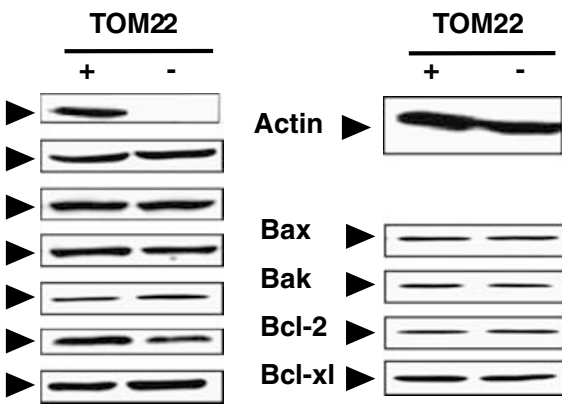

Bax

Bak

Bcl-2

Bcl-xl

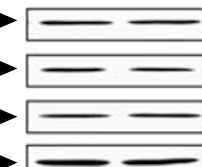

Rest

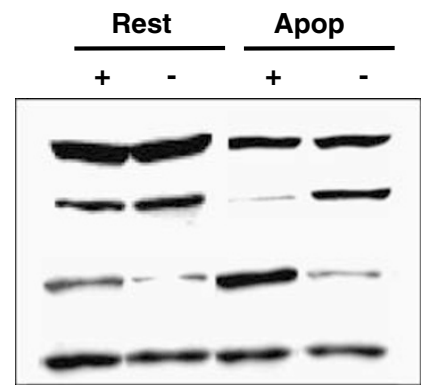

d

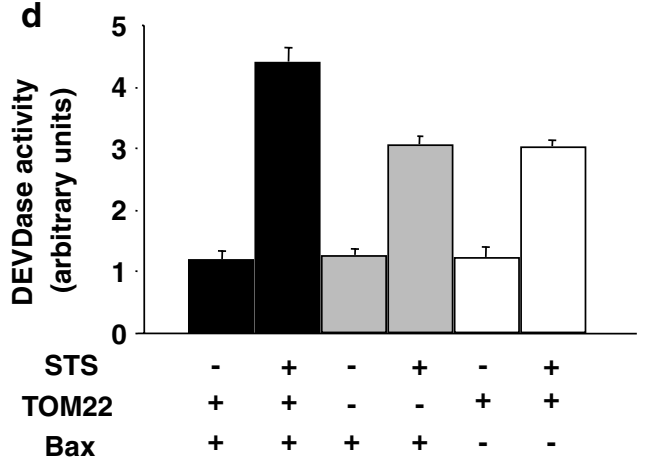

Bax

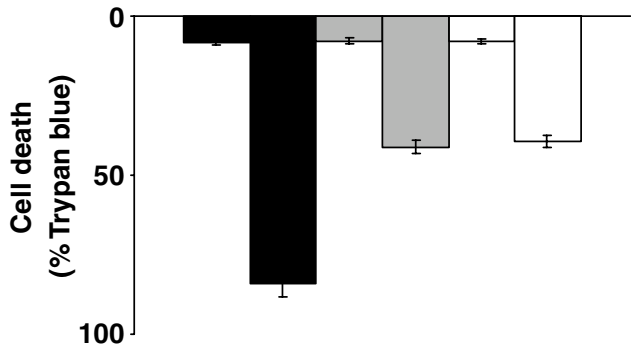

Figure 4 Effect of the transfection of full-length antisense TOM22 CDNA in Bax (+) GBM cells. (a) Confocal analysis of TOM22 expression and pre-COX VIII-RFP subcellular localization in human GBM cells treated with antisense TOM22 or with antisense TOM20 on day 5. Correlation factors (CF) were calculated as described by Cartron et al. ${ }^{5}$ and indicate that the importation of pre-CoX VIII was similarly affected in TOM22 and TOM20 antisense treatments. (b) The expression of key mitochondrial proteins and members of the Bcl-2 family was analyzed by Western blots in GBM cells, treated with TOM22 antisense $(-)$ and compared to that observed in untreated cells $(+)$. Both cells were grown in $3 \%$ glucose culture medium. Data illustrated are representative of three different experiments. (c) Subcellular fractionation and immunoblot analyses of Bax in STS-treated (Apop) and untreated (Rest) TOM22 - and TOM22 + cells. Staining with antibodies raised against cyt $c$ oxidase (subunit IV; Cox) and actin were used, respectively, as controls for mitochondrial and cytosolic fractions. Data illustrated are representative of three different experiments. (d) The response of TOM22- cells to STSinduced apoptosis was compared to that of TOM22 + cells expressing or not Bax. Apoptosis was quantified by measuring cellular caspase activity (i.e. DEVDase) and the percentage of Trypan blue-positive cells. Data illustrated are representative of three different experiments

The interaction between TOM22 and Bax is transient, as revealed by kinetics in crosslinking experiments (Figure 2; Supplementary Figure S1), supporting the hypothesis that the association of Bax with TOM complex is a first step towards the formation of another structure, containing Bax-oligomer and possibly other mitochondrial targets. ${ }^{12}$ The possible involvement of components of the mitochondrial import machinery in the targeting of $\mathrm{Bcl}-2$ have been suggested by Nguyen et al. ${ }^{33}$ and it has been later reported that $\mathrm{Bcl}-2$ interacts with TOM20, a TOM-complex protein. ${ }^{34}$ These 

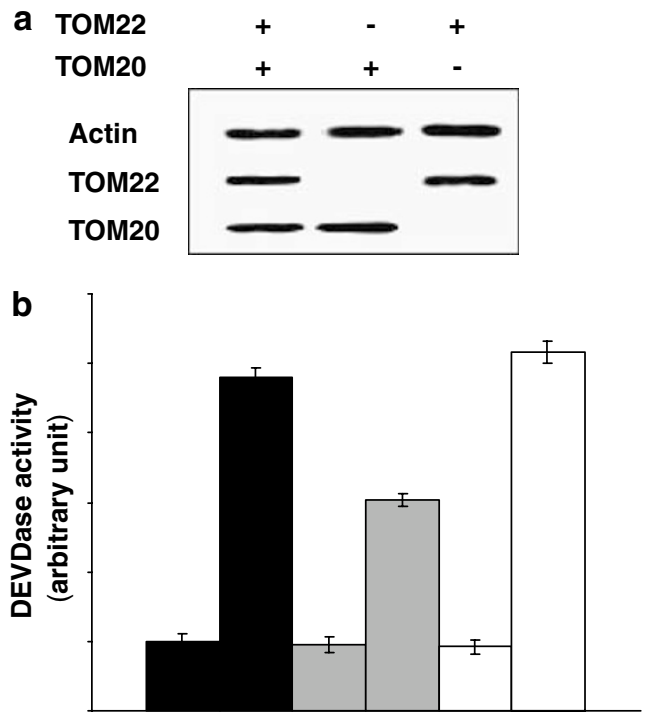

$\begin{array}{ccccccc}\text { STS } & - & + & - & + & - & + \\ \text { TOM22 } & + & + & - & - & + & + \\ \text { TOM20 } & + & + & + & + & - & -\end{array}$

Figure 5 TOM20 AS treatment did not affect STS-induced apoptosis. (a) The expression of TOM20 was analyzed by immunoblots in GBM cells treated with TOM22 or TOM20 antisense and compared to that in untreated cells. Data illustrated are representative of three different experiments. (b) The response to STS-induced apoptosis was compared between TOM20 - and TOM2O + cells. Apoptosis was quantified by measuring cellular caspase activity (i.e. DEVDase) and the percentage of Trypan blue-positive cells. Data (mean and S.D.) were calculated from three different experiments

results suggest that TOM components could play a major role in the control of the mitochondrial localization of the proteins of the $\mathrm{Bcl}-2$ family. It remains to analyze the molecular mechanisms by which TOM22 (and, possibly, other components of the TOM complex) is involved in the apoptotic outer membrane permeabilization. Finally, since Bax also localize to the endoplasmic reticulum to initiate apoptosis, ${ }^{35}$ the mechanism of interaction of Bax with this organelle is still to be determined and in particular its relationship with the organelle import apparatus.

\section{Materials and Methods}

Materials. Unless otherwise stated all cell culture material was obtained from Invitrogen (Cergy Pontoise, France). Monoclonal Bax antibody (clone 4F11) was from Immunotech (Marseille, France) and Monoclonal antibody directed against TOM22 was from Sigma (St Quentin Fallavier, France). Antibodies raised against metaxin 1 and TOM20 were obtained as described, respectively, by Saeki et al., ${ }^{24}$ Armstrong et $a l^{36}$ and Armstrong and Bornstein. ${ }^{37}$ The mitochondrion-selective probe MitoTracker Green-FM was obtained from Molecular Probes (Interchim, Montlucon, France), and fluorogenic peptide AC-DEVD-AMC was from Bachem (Voisins, France). Biochemical reagents used in this study were obtained from Sigma.

\section{Methods}

Acellular binding of IVT proteins to mitochondria. Mitochondria were isolated from rat liver and the association of radio labeled IVT proteins was performed as previously described. ${ }^{10}$ In competition experiments, antibodies (0$15 \mu \mathrm{g}$ ) were incubated with mitochondria at $37^{\circ} \mathrm{C}, 10 \mathrm{~min}$ before the addition of IVT proteins. Phophorlmager (Amersham Biosciences, GE Healthcare, Orray, France)

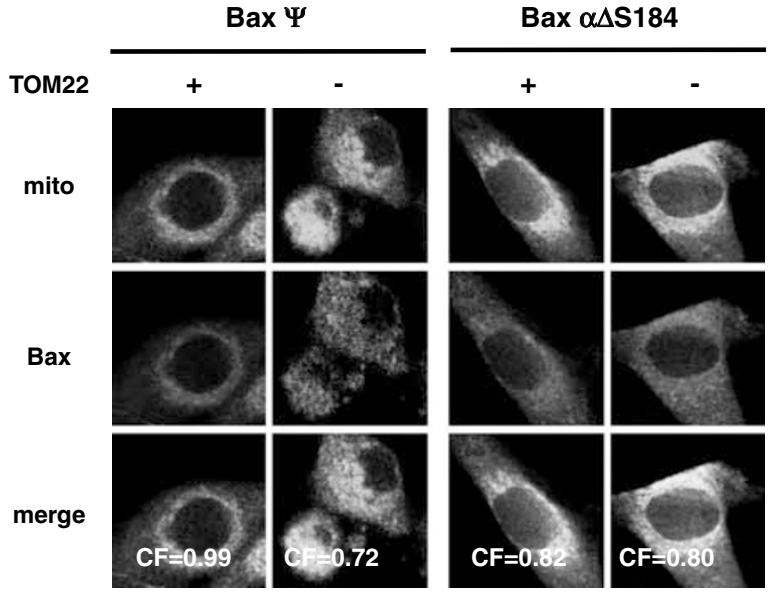

Figure 6 TOM22-AS treatment does not affect Bax $\Delta S 184$ translocation to mitochondria but decreases its amplification of STS-induced apoptosis. Confocal analysis of the subcellular localization of ectopically added $\operatorname{Bax} \Psi$ and $\operatorname{Bax} \Delta \mathrm{S} 184$ in Bax (-) GBM TOM22-AS (TOM22-) and Bax (-) GBM (TOM22 +) cells. Overlay of Bax (-) GBM cells transfected with Bax $\alpha$ and Bax $\Delta S 184$ immunostained with Bax antibodies and MitoTracker green. Correlation factor (CF), calculated from Metamorph analyses of more than 100 cells from five different cells as described by Cartron et al. ${ }^{18}$, indicated that no significant changes in the subcellular localization and in the amount of expression was observed for Bax $\Delta S 184$ in TOM22 (+) or in the TOM22 (-) cells. On the other hand, Bax $\Psi$, which was essentially mitochondrial in TOM22 $(+)$ cells becomes cytosolic in TOM22cells. The pictures are representative of at least 100 different cells. $c f=$ correlation factor

was used to analyze radio labeled proteins present in the mitochondrial pellet after SDS-PAGE separation.

Cell fractionation. TOM22-AS Bax $(+)$ GBM cells $\left(2 \times 10^{6}\right)$ were collected and centrifuged at $800 \times \mathrm{g}$ for $10 \mathrm{~min}$ at $4^{\circ} \mathrm{C}$, washed with ice-cold PBS and resuspended in CEB (v/v) $(250 \mathrm{~mm}$ sucrose, $50 \mathrm{~mm}$ HEPES, pH 7.4, $50 \mathrm{mM} \mathrm{KCl}$, $2 \mathrm{mM} \mathrm{MgCl} 2,1 \mathrm{mM}$ dithiothreitol, $10 \mu \mathrm{M}$ cytochalasin B, $1 \mathrm{mM}$ EGTA and $1 \mathrm{~mm}$ phenylmethylsulfonyl fluoride (PMSF)). Cells were allowed to swell for $30 \mathrm{~min}$ on ice. The cells were then homogenized with 30 strokes in a 2-ml glass Dounce homogenizer. The homogenates were centrifuged at $800 \times g$ for $10 \mathrm{~min}$ at $4^{\circ} \mathrm{C}$, and the resulting supernatants were centrifuged for an additional $15 \mathrm{~min}$ at $13000 \times \mathrm{g}$ at $4^{\circ} \mathrm{C}$ to obtain the mitochondrial pellets (P13). These supernatants were then centrifuged at $100000 \times \mathrm{g}$ for $30 \mathrm{~min}$ in an airfuge centrifuge (Beckman Instruments, France Gagny, France), and the resulting cytosolic fraction was further referred to as the S100. The presence of Bax, actin and cyt c oxidase (subunit IV) was detected in mitochondrial pellets and $\mathrm{S} 100$ using standard Western blot methods.

Confocal analysis. The cells were incubated for $30 \mathrm{~min}$ with $5 \mu \mathrm{g} / \mathrm{ml}$ MitoTracker Green-FM at $37^{\circ} \mathrm{C}$ and then fixed with $1: 1$ methanol/acetone for $15 \mathrm{~min}$ at $-20^{\circ} \mathrm{C}$. After saturation with $3 \%$ bovine serum albumin (BSA) in phosphate-buffered saline, the cells were incubated with antibodies for $1 \mathrm{~h}$ at room temperature. After extensive washing, a second anti-mouse or anti-rabbit IgG coupled to rhodamine was added overnight at $4^{\circ} \mathrm{C}$. Images were collected using a Leica TCS NT microscope with a $63 \times 1.3$ NA Fluotar objective (Leica, Rueil, France).

Induction of apoptosis in vitro. Apoptosis was induced in semiconfluent (50$70 \%)$ GBM cultures by the addition of $2 \mu \mathrm{m} \mathrm{STS}$. Cell death was evaluated $24 \mathrm{~h}$ later as it corresponded in all cases to the maximum loss of cell viability. Apoptosis was quantified by measuring the release of $\mathrm{LDH}$ into the culture medium and the cellular DEVDase activity, as previously described. ${ }^{10}$

Cross-linking. After incubation of mitochondria $(50 \mu \mathrm{g})$ with IVT proteins for different times, crosslinkers DSS or EGS were added in the isotonic HEPES buffer at a final concentration of $5 \mathrm{mM}$ in $1 \mathrm{ml}$. After a 30 min-incubation at room temperature, the crosslinker was quenched by the addition of $1 \mathrm{M} \mathrm{Tris-HCl}(\mathrm{pH} 7.5)$. Subsequently, mitochondrial pellets were analyzed in 12\% SDS-PAGE gels, followed by Phosphorlmager analysis. For IP experiments, mitochondria were solubilized in $100 \mu \mathrm{l}$ Nonidet P-40 (NP-40) isotonic lysis buffer (142.5 mM KCl, $5 \mathrm{~mm}$ 
a

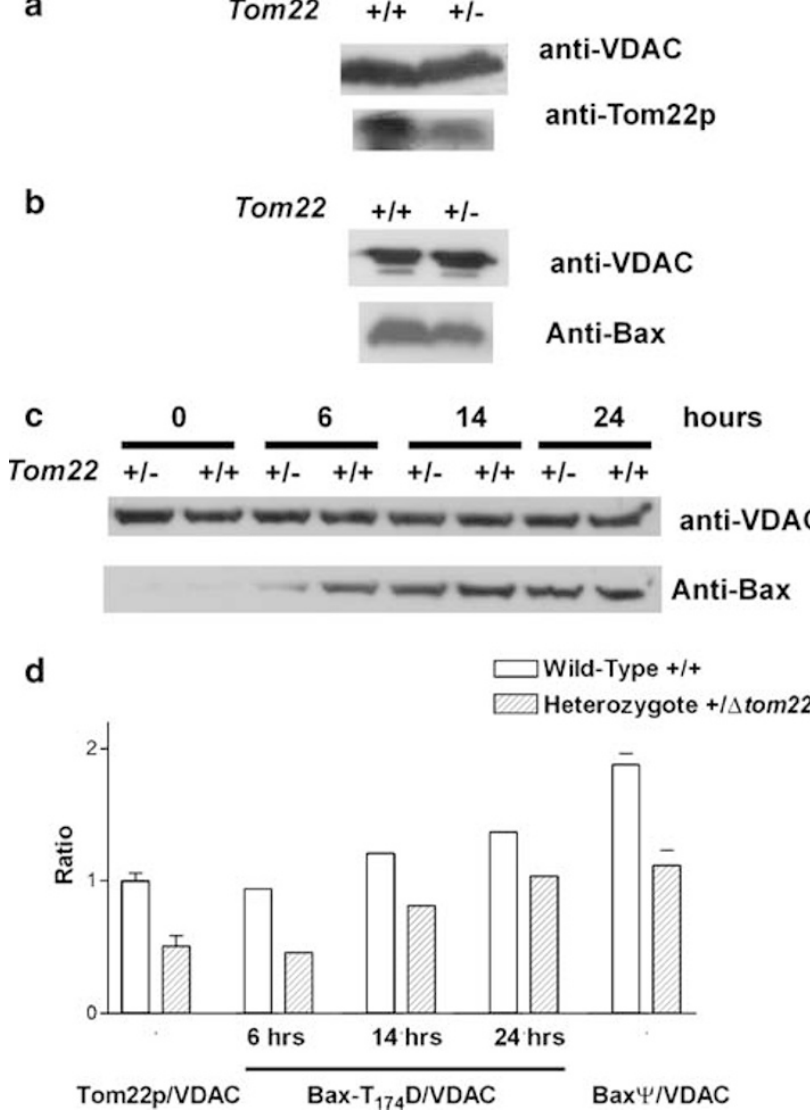

Figure 7 The knockdown of the expression of TOM22 in yeast decrease Bax binding to mitochondria: (a) Wild-type diploid W303D (TOM22 $+/+$ ) or the heterozygote diploid W303D- $\Delta$ tom22 (TOM22 +/-) strains express different amount of the protein TOM22 (TOM22p). VDAC was used an internal control. (b-c) The two strains transformed with pYES plasmids encoding for Bax $\Psi$ (b) or Bax$\mathrm{T}_{174} \mathrm{D}$ (c). Bax-expression was achieved for $14 \mathrm{~h}$ for $\mathrm{Bax} \alpha$ (b) and at the indicated times for $B a x-T_{174} D$ (c). Mitochondria were isolated and proteins were probed with a monoclonal antibody against yeast VDAC (Molecular Probes), polyclonal sera against Bax or yeast Tom22p. Nonsaturated Western blots were scanned and quantified with ImageJ software. (d) Calculation of the amount of Bax (relative to VDAC) bound to mitochondria in the two strains. The average ratio of mitochondrial BaxT $_{174}$ D relative to VDAC was calculated for each point and expressed relatively to the ratio TOM22/VDAC present in the wild-type strain which was arbitrarily fixed at 1

$\mathrm{MgCl} 2,10 \mathrm{~mm}$ HEPES (pH 7.2), $1 \mathrm{~mm}$ EDTA, 0.25\% NP-40, $0.2 \mathrm{~mm} \mathrm{PMSF}, 0.1 \%$ aprotinin, $1 \mu \mathrm{g} / \mathrm{ml}$ pepstatin and $1 \mu \mathrm{g} / \mathrm{ml}$ leupeptin), at $4^{\circ} \mathrm{C}$ for $30 \mathrm{~min}$. Ten micrograms of anti-TOM22, anti-RFP, anti-Bax or anti-TOM20 antibodies were added to each sample, mixed and incubated on ice for $30 \mathrm{~min}$. Then $400 \mu \mathrm{lNP}-40$ buffer and $25 \mu \mathrm{l}$ protein A-Sepharose gel, were added and incubated at $4{ }^{\circ} \mathrm{C}$ overnight with gentle agitation. Immunoprecipitates were collected by a $10 \mathrm{~min}$ centrifugation at $8000 \times \mathrm{g}$, washed three times with $1 \mathrm{ml} \mathrm{NP}-40$ buffer, and were solubilized with SDS before SDS-PAGE and autoradiography analyses.

Microinjection. Microinjection experiments were performed as described by Cartron et al. ${ }^{17}$ Briefly, cells were seeded on glass coverslips $24 \mathrm{~h}$ prior microinjection using microcapillaries (femtotips II, Eppendorf) mounted on an automated microinjection system (Eppendorf). Antibodies at the indicated concentrations in PBS together with dextran $(70 \mathrm{kDa})$-conjugated lysine fixable Oregon green ( $0.5 \%$ final concentration; Molecular Probes) as a coinjection marker were microinjected. Typically, 100-150 cells were microinjected using identical pressures $(150 \mathrm{hPa})$ and times $(0.1 \mathrm{~s})$.

Peptide scan. Interaction of TOM22 and VDAC with Bax was performed using 12 mer peptides and a two amino-acid frame shift, generating 91 peptides. Peptides were spotted on an Amino-PEG - $_{00}$-UC540 membrane using a MultiPep peptide synthesizer (Intavis AG, Cologne, Germany) at a loading capacity of $400 \mathrm{nmol} / \mathrm{cm}^{2}$. After synthesis the membrane was dried then the capped side-chains were deprotected by cleavage for $2 \mathrm{~h}$ with a cocktail containing 95\% TFA, 3\% triisopropyl, $2 \% \mathrm{H}_{2} \mathrm{O}$. TFA was removed and the membrane rinsed with dichloromethane, followed by ethanol and then $\mathrm{H}_{2} \mathrm{O}$. The membrane was dried before use. Mitochondria were lysed in $50 \mathrm{mM} \mathrm{NaCl}, 5 \mathrm{~mm}$ 6-hexanoic acid, $50 \mathrm{mM}$ imidazole, CHAPS $1 \%, \mathrm{pH} 7.0$ on ice for $30 \mathrm{~min}$, then centrifuged $10 \mathrm{~min}$ at $16000 \times g$. Membranes were saturated with 5\% BSA-PBS, and then incubated with $2 \mathrm{mg} / \mathrm{ml}$ mitochondrial extract. After which, it was washed three times with $1 \%$ BSA-PBS then positive spots were revealed as primary antibodies polyclonal antiTOM22 and VDAC antibodies and secondary antibodies were revealed by the BM chemiluminescence kit (Roche Diagnostics). The binding intensities of TOM22 or VDAC for Bax-derived peptides were determined by quantification using IP-Lab Gel software (Signal Analytics, Vienna, Va, USA) and converted to sequence-specific normalized units. The intensities obtained for each peptide covering a given amino acid were added and divided by the number of peptides.

Transfection of full-length antisense TOM22and TOM20. To inhibit the expression of TOM22 or TOM20 in Bax $(+)$ and Bax $(-)$ GBM cells, cells were transfected with two consecutive electroporations with $10 \mu \mathrm{g}$ plasmid encoding for the anti-full-length sequence of human TOM22 or TOM20. The bulk of cells were selected for 20 days with $250 \mu \mathrm{g} / \mathrm{ml} \mathrm{G} 418$ and frozen to avoid clonal bias. TOM22AS cells were cultured for no longer than 5 days in high glucose medium (3\%) before analysis in order to avoid viability loss due to the lack of expression of TOM22. Trypsin treatment of mitochondria. Mitochondria $(1 \mathrm{mg})$ were treated with 5 or $50 \mu \mathrm{g}$ trypsin for $30 \mathrm{~min}$ at $0^{\circ} \mathrm{C}$ in $1 \mathrm{ml}$ isotonic buffer $(210 \mathrm{~mm}$ mannitol; $70 \mathrm{mM}$ sucrose; $5 \mathrm{~mm}$ HEPES, pH 7.5; $1 \mathrm{~mm}$ EDTA). At the end of the incubation, $5 \mu \mathrm{g}$ bovine trypsin pancreatic inhibitor and $1 \mathrm{mM}$ PMSF was added. Control mitochondria were treated similarly using $50 \mu \mathrm{g} \mathrm{BSA}$ as a mock treatment followed by incubation with $5 \mu \mathrm{g}$ bovine trypsin pancreatic inhibitor and $1 \mathrm{mM}$ PMSF. IVT proteins were then added to treated or mock-treated mitochondria and their binding to the organelle was analyzed as described above.

Yeast experiments. The TOM22:kanMX4 cassette was amplified by PCR from the genomic DNA of the strain Y22945 (Euroscarf collection, Frankfurt, Germany). The PCR fragment was used to transform the W303D diploid strain (mat a/ $\alpha$, ade2/ ade2, his3/his3, leu2/leu2, trp1/trp1, ura3/ura3) and selected for the resistance to geneticin $(400 \mu \mathrm{g} / \mathrm{ml})$. As the complete absence of TOM22 is lethal, only the heterozygote could survive. The presence of the disruption cassette was verified by PCR with one primer located in the promoter of TOM22 and one located inside the gene kanMX4. W303D and W303D-Dtom22 were transformed with plasmids pYES3-Bax $\Psi$ and pYES3-Bax- $T_{174} \mathrm{D}^{38}$ and selected for growth in the absence of uracile and tryptophan, respectively. These plasmids expressed these active variants of Bax under the control of the regulatable promoter GAL1/10. Cells were grown aerobically in a lactate-supplemented SD medium and Bax-expression was induced by the addition of $1 \%$ galactose. Cells were harvested, mitochondria were isolated and quantifications of the different mitochondrial proteins was performed by Western blot analysis. ${ }^{10}$

Blue Native PAGE. Blue native PAGE (BN-PAGE) was performed essentially as described in http://www.hos.ufl.edu/clineweb/Protocols/BNgel.htm. Briefly, mitochondrial membranes were suspended at $0.8 \mathrm{mg} / \mathrm{ml}$ in imidazole/ $\mathrm{HCl}$ buffer (pH 7.0) containing $50 \mathrm{mM} \mathrm{NaCl}$ and $5 \mathrm{mM} \varepsilon$-aminocaproic acid. Digitoninsolubilization was performed for $20 \mathrm{~min}$ on ice at a detergent/protein ratio of $3(\mathrm{w} / \mathrm{w})$. Unsolubilized material was sedimented $(21000 \times \mathrm{g}, 20 \mathrm{~min})$ and discarded. The supernatant was supplemented with Coomassie dye solution ( $5 \%$ Serva Blue $G$ in $750 \mathrm{mM} \varepsilon$-aminocaproic acid) to a dye/protein ratio of $0.2(\mathrm{w} / \mathrm{w})$ and separated on a linear gradient (5-14\%) polyacrylamide slab gel. Molecular weight markers were treated in a similar manner before loading on the gel.

Second dimension electrophoresis was performed on each individual lane from the BN-PAGE. Lanes were excised and incubated in the dissociating solution (1\% SDS, $1 \% \beta$-mercaptoethanol) for $3 \mathrm{~h}$ at room temperature. The lane was layered on the top of a glycine-SDS-12.5\% polyacrylamide gel. After migration, proteins were blotted on PVDF membranes (ProBlott, Applied Biosystems, VWR international, SA, France). Antibodies directed against Bax (N20, Santa-Cruz, Tebu-Bio, France), Tom22 (Santa-Cruz) and Tom40 (Santa-Cruz) were used at $1 / 2000^{\circ}, 1 / 500^{\circ}$ and $1 /$ $500^{\circ}$ dilutions, respectively. HRP-coupled secondary antibodies (Jackson Laboratories, Maine, USA) were used at $1 / 5000^{\circ}$. Peroxidase activity was revealed with $\mathrm{ECL}+$ (Amersham) 
20. Cartron PF, Gallenne T, Bougras G, Gautier F, Manero F, Vusio P et al. The first helix of Bax plays a necessary role in its ligand-induced activation by the $\mathrm{BH} 3$-only proteins BID and PUMA. Mol Cell 2004; 16: 807-818.

Acknowledgements. We thank Dr. N. Vita (Sanofi Recherche) for the gift of the anti-PBR antibodies and Dr. Carla Koehler (UCLA) for the polyclonal serum against yeast Tom22p. This work was supported by grants from INSERM, Université de Nantes and 'Ligue Nationale contre le Cancer' ('Programme Equipe Labellisée Ligue').

1. Adams JM. Ways of dying: multiple pathways to apoptosis. Genes Dev 2003; 17 2481-2495.

2. Danial NN, Korsmeyer SJ. Cell death: critical control points. Cell 2004; 116: 205-219.

3. Suzuki M, Youle RJ, Tjandra N. Structure of Bax: coregulation of dimer formation and intracellular localization. Cell 2000; 103: 645-654.

4. Heimlich G, McKinnon AD, Bernardo K, Brdiczka D, Reed JC, Kain R et al. Bax-induced cytochrome $c$ release from mitochondria depends on alpha-helices- 5 and -6 . Biochem $J$ 2004; 378: 247-255

5. Cartron P-F, Arokium H, Oliver L, Meflah K, Manon S, Vallette FM. Distinct domains control the addressing and the insertion of Bax into mitochondria. J Biol Chem 2005; 280: 10587-10598.

6. Hsu YT, Wolter KG, Youle RJ. Cytosol-to-membrane redistribution of Bax and $\mathrm{Bcl}-\mathrm{X}(\mathrm{L})$ during apoptosis. Proc Natl Acad Sci USA 1997; 94: 3668-3672.

7. Schinzel A, Kaufmann T, Borner C. Bcl-2 family members: intracellular targeting, membrane-insertion, and changes in subcellular localization. Biochim Biophys Acta 2004 1644: 95-105

8. Kaufmann T, Schlipf S, Sanz J, Neubert K, Stein R, Borner C. Characterization of the signal that directs $\mathrm{Bcl}-\mathrm{xL}$, but not $\mathrm{Bcl}-2$, to the mitochondrial outer membrane. J Cell Biol 2003; 160: 53-64.

9. Nechushtan A, Smith CL, Hsu YT, Youle RJ. Conformation of the Bax C-terminus regulates subcellular location and cell death. EMBO J 1999; 18: 2330-2341.

10. Cartron P-F, Priault M, Oliver L, Meflah K, Manon S, Vallette FM. The N-terminal End of Bax Contains a Mitochondrial-targeting Signal. J Biol Chem 2003; 278: 11633-11641.

11. Linseman DA, Butts BD, Precht TA, Phelps RA, Le SS, Laessig TA et al. Glycogen synthase Kinase-3 phosphorylates Bax and promotes its mitochondrial localization during neuronal apoptosis. J Neurosci 2004; 24: 9993-10002.

12. Kuwana TMM, Perkins G, Ellisman MH, Latterich M, Schneiter R, Green DR et al. Bid, Bax, and lipids cooperate to form supramolecular openings in the outer mitochondrial membrane. Cell 2002; 111: 331-342.

13. Jürgensmeier J, Xie Z, Deveraux Q, Ellerby L, Bredesen D, Reed J. Bax directly induces release of cytochrome $c$ from isolated mitochondria. PNAS 1998; 95: 4997-5002.

14. Roucou X, Montessuit S, Antonsson B, Martinou JC. Bax oligomerization in mitochondrial membranes requires tBid (caspase-8-cleaved Bid) and a mitochondrial protein. Biochem $J$ 2002; 368: 915-921.

15. Schinzel A, Kaufmann T, Schuler M, Martinalbo J, Grubb D, Borner C. Conformational control of Bax localization and apoptotic activity by Pro168. J Cell Biol 2004; 164 1021-1032.

16. Pfanner N, Muller H, Harmey M, Neupert W. Mitochondrial protein import: involvement of the mature part of a cleavable precursor protein in the binding to receptor sites. EMBO 1987; 6: 3449-3454.

17. Cartron PF, Juin P, Oliver L, Martin S, Meflah K, Vallette FM. Nonredundant role of Bax and Bak in bid-mediated apoptosis. Mol Cell Biol 2003; 23: 4701-4712.

18. Cartron PF, Oliver L, Martin S, Moreau C, LeCabellec MT, Jezequel P et al. The expression of a new variant of the pro-apoptotic molecule Bax, Baxpsi, is correlated with an increased survival of glioblastoma multiforme patients. Hum Mol Genet 2002; 11: 675-687.

19. Cartron PF, Oliver L, Juin P, Meflah K, Vallette FM. The p18 truncated form of Bax behaves like a Bcl-2 homology domain 3-only protein. J Biol Chem 2004; 279: 11503-11512.
21. Ahting U, Thieffry M, Engelhardt H, Hegerl R, Neupert W, Nussberger S. Tom40, the poreforming component of the protein-conducting TOM channel in the outer membrane of mitochondria. J Cell Biol 2001; 153: 1151-1160.

22. Truscott KN, Brandner K, Pfanner N. Mechanisms of protein import into mitochondria. Curr Biol 2003; 13: R326-R337.

23. Van Wilpe Sandra RMT, Hill K, Maarse Ammy C, Meisinger C, Brix J, Dekker Peter JT et al. Tom22 is a multifunctional organizer of the mitochondrial preprotein translocase. Nature

24. Saeki K, Suzuki $\mathrm{H}$, Tsuneoka M, Maeda M, Iwamoto $\mathrm{R}$, Hasuwa $\mathrm{H}$ et al. Identification of mammalian TOM22 as a subunit of the preprotein translocase of the mitochondrial oute membrane. J Biol Chem 2000; 275: 31996-32002.

25. Brix J, Rudiger S, Bukau B, Schneider-Mergener J, Pfanner N. Distribution of binding sequences for the mitochondrial import receptors Tom20, Tom22, and Tom70 in a presequence-carrying preprotein and a non-cleavable preprotein. J Biol Chem 1999; 274 16522-16530

26. Narita M, Shimizu S, Ito T, Chittenden T, Lutz R, Matsuda $\mathrm{H}$ et al. Bax interacts with the permeability transition pore to induce permeability transition and cytochrome $c$ release in isolated mitochondria. J Biol Chem 1998; 95: 14681-14686.

27. Sollner T, Griffiths G, Pfaller R, Pfanner NWN. MOM19, an import receptor for mitochondrial precursor proteins. Cell 1989; 59: 1061-1070.

28. Martinou J, Green D. Breaking the mitochondrial barrier. Nat Rev Mol Cell Biol 2001; 2 $63-67$.

29. Roucou X, Rostovtseva T, Montessuit S, Martinou JC, Antonsson B. Bid induces cytochrome $c$-impermeable Bax channels in liposomes. Biochem $\mathrm{J} 2002 ; 363$ $547-552$

30. Tan K, Fu N, Sukumaran S, Chan S, Kang J, Poon B et al. MAP-1 is a mitochondrial effector of Bax. Proc Natl Acad Sci (USA) 2005; 102: 14623-14628.

31. Newmeyer DD, Ferguson-Miller S. Mitochondria: releasing power for life and unleashing the machineries of death. Cell 2003; 112: 481-490.

32. Nouraini S, Six E, Matsuyama S, Krajewski S, Reed JC. The putative pore-forming domain of Bax regulates mitochondrial localization and interaction with $\mathrm{Bcl}-\mathrm{X}(\mathrm{L})$. Mol Cell Biol 2000 ; 20: $1604-1615$

33. Nguyen M, Millar D, Yong V, Korsmeyer SGCS. Targeting of Bcl-2 to the mitochondrial outer membrane by a $\mathrm{COOH}$ - terminal signal anchor sequence. J Biol Chem 1993; 268 : 25265-25268.

34. Motz C, Martin $\mathrm{H}$, Krimmer $\mathrm{T}$, Rassow J. Bcl-2 and porin follow different pathways of TOM-dependent insertion into the mitochondrial outer membrane. J Mol Biol 2002; 323: 729-738.

35. Zong W-X, Li C, Hatzivassiliou G, Lindsten T, Yu Q-C, Yuan J et al. Bax and Bak can localize to the endoplasmic reticulum to initiate apoptosis. J Cell Biol 2003; 162 $59-69$.

36. Armstrong LC, Komiya T, Bergman BE, Mihara K, Bornstein P. Metaxin is a component of a preprotein import complex in the outer membrane of the mammalian mitochondrion J Biol Chem 1997; 272: 6510-6518.

37. Armstrong LCSA, Bornstein P. Metaxin 1 interacts with metaxin 2, a novel related protein associated with the mammalian mitochondrial outer membrane. J Cell Biochem 1999; 74 11-22.

38. Arokium H, Camougrand N, Vallette FM, Manon S. Studies of the interaction of substituted mutants of Bax with yeast mitochondria reveal that the $\mathrm{C}$-terminal hydrophobic a-helix is a second ART sequence, and plays a role in the interaction with anti-apoptotic $\mathrm{Bcl}-\mathrm{xL}$. J Bio Chem 2004; 279: 52566-52573. 1999; 401: 485-489.

\section{Supplementary Information accompanies the paper on Cell Death and Differentiation website (http://www.nature.com/cdd)}

